This is an electronic reprint of the original article. This reprint may differ from the original in pagination and typographic detail.

Author(s): Pappa, Sotiria; Moate, Josephine; Ruohotie-Lyhty, Maria; Eteläpelto, Anneli

Title: $\quad$ Teacher agency within the Finnish CLIL context : tensions and resources

Year: $\quad 2017$

Version:

Please cite the original version:

Pappa, S., Moate, J., Ruohotie-Lyhty, M., \& Eteläpelto, A. (2017). Teacher agency within the Finnish CLIL context : tensions and resources. International Journal of Bilingual Education and Bilingualism, 65, 61-70.

https://doi.org/10.1080/13670050.2017.1286292

All material supplied via JYX is protected by copyright and other intellectual property rights, and duplication or sale of all or part of any of the repository collections is not permitted, except that material may be duplicated by you for your research use or educational purposes in electronic or print form. You must obtain permission for any other use. Electronic or print copies may not be offered, whether for sale or otherwise to anyone who is not an authorised user. 


\section{Teacher Agency within the Finnish CLIL Context: Tensions and Resources}

\section{Sotiria Pappa}

Department of Education, University of Jyväskylä

Ruusupuisto D423.6, P.O. Box 40014, University of Jyväskylä, Finland +358 408053832; $\underline{\text { sotiria.s.pappa@jyu.fi }}$

Josephine Moate

Department of Teacher Education, University of Jyväskylä

Ruusupuisto D222.2, P.O. Box 40014, University of Jyväskylä, Finland +358 408057795; josephine.moate@jyu.fi

Maria Ruohotie-Lyhty

Department of Teacher Education, University of Jyväskylä

Ruusupuisto D222.1, P.O. Box 40014, University of Jyväskylä, Finland +358 408057726; maria.ruohotie-lyhty@jyu.fi

Anneli Eteläpelto

Department of Education, University of Jyväskylä

Ruusupuisto D437, P.O. Box 40014, University of Jyväskylä, Finland +358 408057669; anneli.etelapelto@jyu.fi 


\title{
Teacher Agency within the Finnish CLIL Context: Tensions and Resources
}

\author{
Recent discussion indicates that the initial enthusiasm of Content and Language \\ Integrated Learning (CLIL) teachers can be undermined by the demands of \\ foreign-language mediated education. However, there is a lack of research on the \\ resources and tensions that respectively support or limit the professional agency \\ of CLIL teachers. By means of semi-structured interviews with fourteen \\ participants, this study seeks to better understand how teacher agency is \\ experienced by CLIL teachers working in Finnish primary schools. To examine \\ tensions and resources in CLIL teachers' work lives, a holistic and dynamic \\ theoretical conceptualization of teacher agency is suggested, paying particular \\ attention to the classroom, professional relationships and the wider sociocultural \\ environment. Findings showed that language, classroom-related tensions and \\ temporal, material and developmental resources were perceived as tensions \\ limiting teacher agency. In contrast, autonomy, openness to change, teacher \\ versatility, and collegial community were found to support teacher agency. The \\ study concludes with practical implications for teacher education, practicing \\ teachers and future research.
}

Keywords: Content and Language Integrated Learning (CLIL); teacher agency; perceived tensions; perceived resources; Finnish education

\section{Introduction}

Content and Language Integrated Learning (CLIL) is a well-established approach in language education. CLIL intentionally seeks to develop foreign language (FL) learning by using the FL in subject classrooms, that is to teach and learn, for example, history, physics, religion or physical education through a FL. Whilst initially CLIL sought to promote FL learning without harming subject learning (Masih 1999), in recent times CLIL has been promoted as a means to enrich subject as well as FL learning (e.g. Baetens-Beardsmore 2008). As CLIL has been introduced in many European contexts (see Eurydice 2014), this versatile methodology has taken on many different forms from 
small language 'showers' to more extensive forms of bilingual education. Various projects have been funded at a European level to develop more systematic approaches to CLIL pedagogy (e.g. Marsh et al. 2014), yet whether or not CLIL teachers receive specific support for the implementation and development of CLIL pedagogy is less clear. A number of different research reports indicate that the initial enthusiasm of CLIL teachers can be undermined by the demands of foreign-language mediated education (e.g. Lehti, Järvinen and Suomela-Salmi 2006). Although CLIL teachers are not required to have a native command of the target language (e.g. Marsh 2012), the limitations of working through a FL, such as the lack of humour, materials, collegial support (e.g. Lehti et al. 2006), and the additional tensions when supporting pupils' learning through a FL (e.g. Moate 2013) can be overwhelming.

Recent research has sought to better understand the tensions CLIL teachers face by investigating, for example, how CLIL teachers develop materials (Bovellan 2014), how teacher selves change when working through a foreign language (Nikula 2010), and how teacher communities can support CLIL development (Moate 2014). Other CLIL research has focused more specifically on the use of language in CLIL - both the language that is used and the language that perhaps should be used (e.g. Morton 2012) as well as learner development in CLIL (Dalton-Puffer 2011). Teachers, however, are central mediators in the classroom, responsible for building the relationship between the pupils and the subject, monitoring and guiding pupil development, representing subject knowledge in the appropriate language, and creating an environment that supports the learning of different pupils. If CLIL limits teacher capacity in any of these areas, it is potentially detrimental to the learning capacity of the classroom environment - although this is not intended to suggest a causal relationship between teaching and learning. However, there is a lack of research on the resources and tensions that support or limit 
CLIL teachers' professional agency, understood here as actively influencing, making choices and taking stances at work.

Taking a qualitative approach, the research reported here seeks to better understand how teacher agency is experienced by CLIL teachers working in Finnish primary schools (grades 1-6, ages 7-13). Teacher agency is examined in the light of perceived tensions and resources, taking into consideration how individual and contextual factors interact in Finnish CLIL education. The findings are explained in light of a holistic and dynamic theoretical conceptualization of teacher agency. In this conceptualization, teacher agency is comprised of three types pertaining to the different work contexts of CLIL teachers. Particular attention is paid to the classroom, professional relationships and the wider sociocultural environment in which teachers act and interact, examining factors at play within the scope of Finnish CLIL teachers' pedagogical, relational and sociocultural agency respectively. In the following sections, the theoretical framework and the context for this study are outlined in more detail.

\section{Theoretical Framework}

Agency is a concept that has recently received a significant amount of attention in educational research and it is often understood as the mediated capacity to act within hegemonic discourses and sociocultural frameworks (Ahearn 2001; Eteläpelto et al. 2013). Therefore, teacher agency is the way in which teacher intention and understanding is enacted within a particular environment, whether physical, emotional, social, pedagogical or professional. This concept is useful because it draws attention to the sensitive space between an individual's hopes and plans, and their realized or realizable potential. We contend that if the agency of CLIL teachers is significantly constrained, CLIL teaching will be less successful and negatively impact on teachers' 
well-being. On the other hand, a better understanding of CLIL teacher agency should help in the further development of professional development programmes and courses for teachers, as well as the development of appropriate materials, resources and environments for CLIL.

Agency is a situated activity, something the individual does within contexts-foraction characterized by particular interactive ecological circumstances influenced by time, relations, and a potential for transformation and achievement (Biesta, Priestley, and Robinson 2015). To gain a more comprehensive understanding of what constitutes teacher agency within the particular context of CLIL, teacher agency is proposed as a dynamic concept involving an interrelation between pedagogical, relational and professional agency. Pedagogical agency is enacted within the classroom domain; that is, material selection and usage, selection and execution of instructional strategies, classroom management, performance of the teacher role and decision-making for pupil learning, engagement and better academic performance. It is important that teachers are able to influence and negotiate "core pedagogical and instructional practices, including applying new ideas at work, making decisions on one's ways of teaching, and developing one's work", an ability that is meaningful only when teachers "feel in control of the choices they make within their work" (Eteläpelto, Vähäsantanen, and Hökkä 2015, 663).

Whereas pedagogical agency highlights the relationship between teachers and pupils, relational agency reflects collegial relationships in light of sharing experiences and knowledge with colleagues. This type of agency involves reciprocal, mutual relationships in strengthening expertise, but also advocates a focus on the nature of the relationships that mediate between individual interpretations and the social at work for the sake of distributing expertise and enhancing collective competence (Edwards 2007). 
Teacher development can occur when teachers jointly consider and openly discuss classroom reality and practices, the meaning of their experiences and their conceptualization of pedagogies, as this creates space for teachers to find a voice together through exploratory talk, articulate their needs, seek and offer help, and validate a sense of being and becoming in a teacher community (e.g. Moate 2014). Sociocultural agency, however, goes beyond the immediate school environment to the wider sociocultural environment, including stakeholders like parents, policy-makers and other authorities. These three different components align with a sociocultural account of agency as "an essentially mediated phenomenon" (Ruohotie-Lyhty and Moate 2015, 59 ), with teachers acting in a reactive or proactive manner, willingly or grudgingly, to educational policies, aims, expectations and demands. This perspective suggests that teacher agency is tethered to these three components of agency and evident in the way teachers respond to pupils, colleagues, external forces, expectations and aspirations. Thus, it may offer a more inclusive view of influences on CLIL teachers' agency, its expression in the CLIL classroom and its impact on the implementation of this methodology.

\section{Context for the Research}

Being complementary to traditional and formal foreign language instruction, CLIL has been a popular means of effecting bilingual or FL education through the curriculum for many decades. CLIL aims at motivating pupils in language learning and offers a wider space for academic achievement and linguistic awareness through dialogic practices (Coyle 2006; Baetens-Beardsmore 2008). Moreover, while not so different from other language-based initiatives (e.g. content-based language education or immersion education) in terms of aim, there is a significant difference in the teacher's relationship 
with the language, which yields the opportunity to re-conceptualize the content, purpose and processes of the curriculum (Tedick and Cammarata 2012). This is reflected in the new Finnish curriculum put into effect in August 2016, which particularly emphasizes language-aware education, cultural knowledge and multilingual orientation (FNBE 2014; Bergroth 2016).

Finland has been among the first European countries to introduce CLIL to its education system and continues to conduct considerable research in CLIL and to offer teacher training programmes for prospective CLIL teachers (e.g. JULIET in Jyväskylä). Section 10 of the Finnish Basic Education Act (Ministry of Education, 1998) states that instruction provided through a foreign language may be done partly or entirely, so long as it does not obstruct pupils' ability to follow teaching. Bergroth (2016) clarifies that the Finnish core curriculum is an administrative, intellectual and pedagogical document following a backward design, whereby learning objectives are stipulated in educational policy and then interpreted, developed and implemented by educational providers and teachers, taking into account local needs. However, there are no prescribed or recommended teaching methods for bilingual education or any restrictive definition of it. The author argues that this is because the national curriculum would otherwise compromise teacher autonomy and local decision-making about the extent and character of the bilingual education provided (e.g. large- or small-scale programmes where respectively $25 \%$ of the curriculum or less is taught in the target language). With no official bilingual schools and bilingual education being intertwined with general language education (Bergroth 2016), CLIL implementation is versatile and potentially vulnerable, despite common objectives and shared principles. However, for Finnish CLIL to be able to make the most of this opportunity, it is important to understand what teachers need to be able to succeed in CLIL teaching. 
It would be safe to assume the majority of pre-service CLIL teachers are not fully prepared upon graduation for the practical and difficult aspects of the teaching profession. However, general guidelines in conjunction with the inherent difficulty of the methodology and the day-to-day reality of the classroom render CLIL a challenge for more experienced teachers as well. Although teachers in Finland are considered and indeed expected to be autonomous practitioners in fulfilling curricular and pedagogical requirements, they still need support, especially given the professional challenge of teaching one's subject through the medium of a foreign language. Examining what enables and restrains the professional agency of teachers might not only bring to the forefront factors that affect CLIL implementation in Finnish schools, but also provide discursive space for teachers' professional development. In the following sections, the research questions and methods are outlined.

\section{Research Questions}

This study aims at examining factors that negatively or positively influence teacher agency in Finnish primary school CLIL education. The combined components of pedagogical, relational and sociocultural agency serve as a dynamic conceptualization of teacher agency, which provides the background to the following research questions:

(1) What tensions do CLIL teachers in Finland recognize in exercising agency in their work?

(2) What enables and resources CLIL teachers in Finland to deal with tensions at work? 


\section{Methods}

\section{Participants}

Thirteen primary school and one kindergarten CLIL teachers participated in the study. As well as Finnish participants, one international teacher was included in the study. The language of CLIL instruction was English. The participants were women, fluent in English, working in seven different schools. With the exception of one experienced teacher who had become familiar with CLIL through her colleagues, all teachers had completed university-level courses in CLIL (see Table 1). In addition, some participants (Teachers 3, 12, 13 and 14) had experience teaching abroad. One had spent 12 years in special education before teaching CLIL, and three others taught special education classes parallel to CLIL. Three teachers explicitly mentioned following the school's policy on CLIL, and all participants saw CLIL teaching as an interesting challenge to their teaching whether when coming into contact with it during their studies and internship, or when changing work places.

[insert Table 1 near here]

\section{Research Design and Data Collection}

Initially, a preliminary differentiation between three different forms of agency was developed based on a review of the existing literature drawing principally on professional and teacher agency. One of the underlying motivations for the study was whether this differentiation corresponded with the reported experiences of teachers and whether the reported experiences could enrich the differentiation. The interviews included questions corresponding to each feature of these components, which were then refined to relate to CLIL teaching and organized in an easy-to-follow sequence, so that 
the data could yield a narrative-like account of the teachers' agency. The questions were open-ended and focused on teachers' experiences, opinions and knowledge, for example:

- Do you have any memorable experiences that have made you the teacher you are today?

- What do teaching and learning mean to you?

- What are the most common positive feelings you have when you teach CLIL?

- How would you describe your relationships with colleagues at school?

Some questions included comparing CLIL teaching to L1 teaching and self-to-self so as to make existing differences more prominent and facilitate self-disclosure in a safe environment devoid of notions of self-other judgment (Moate 2011). The interviews were semi-structured, so as not to impose a structure on the narrative and to allow participants to expand on their experiences and perceptions within a shared frame (Holloway and Jefferson 2000). The data were collected from October to midDecember 2015. Participants were informed about the methods, purpose of the study and ethical commitments, while an informed consent form was signed prior to the interviews.

\section{Data Analysis}

The audiotaped interviews lasted from half to a full hour and were transcribed verbatim. Preliminary differentiation was used to conduct an abductive thematic analysis of the data (Patton 2015). Thematic analysis is a useful, widely used and flexible approach that not only allows access to and identification of themes and patterns related to both epistemology and research questions, but also produces rich interpretation of data sets 
and insightful analysis when anchored to an existing theoretical framework (Patton 2015). An abductive thematic analysis recognizes that the researcher can refer to former research in the relevant area and draw on statements or conclusions present therein (Vaismoradi et al. 2016). An example of how the data were analysed is presented in Table 2, while a more detailed description of reduction from codes to themes is available in Appendix A.

[insert Table 2 near here]

The data analysis was subjected to consultation and constructive criticism by the primary author and co-authors. Research triangulation was applied to increase the credibility of the study. All interview data was examined thoroughly and has not been manipulated or edited. The excerpts used in this study serve to illustrate the identified themes and their relevance and accuracy has been examined by means of review by coauthors and participants.

\section{Findings}

In this section, the findings are presented according to the order of the research questions. Thus, perceived tensions are presented first and resourcing factors are presented second.

\section{Perceived Tensions}

Tensions could be perceived as either constraining or facilitating teacher agency depending on how they were perceived by the CLIL teachers. In the analysis, three themes describing challenging and tensioned factors were identified: i) language as a tension, ii) classroom-related tensions, and iii) availability of temporal, material and developmental resources. In the following section, these themes are described in more 
detail and illustrated with examples.

\section{Language as a Tension}

Language featured often in the interviewees' responses (11/14), which could be expected since CLIL involves a language other than the mother tongue for teacher and pupils alike. In general, CLIL was viewed as a holistic approach, complementary to regular or foreign language classes, but also as an extra challenge (5/14) for all parties concerned. Teachers talked about open-endedness to their questions, pupils' natural use of language over time, more active learning and focusing. However, language can be a cognitive load for pupils, while teachers might feel constricted in the quantity and level of difficulty of language they can use:

Because for many, uh, just the idea that somebody is talking to you on a foreign language, that might be a huge barrier. So I think, uh, teacher had to know the pupil really well on the quantity of the language, foreign language, used in the classroom (Teacher 8)

At this point, a little bit yes, because language is so central to teaching, it's so central to who we are. And when I use a different language, and especially because it's a second language for the kids, I don't get to express myself in a same way. Kinda narrows the expression down a little bit (Teacher 9)

Therefore, while 'our learning is based a lot on language' (Teacher 6) and 'you teach in the language you want students to learn' (Teacher 13), a lot of visual material, and time allotted to clarification and vocabulary learning are necessary. Language might become a 'natural tool' over time and through continuous collaboration with pupils, but some teachers $(5 / 14)$ commented that pupil behaviour in class might change because of it. For example, '[pupils] have a lot of negotiation' (Teacher 6) and try 'finding the answers themselves' (Teacher 7), but not all pupils find it easy to participate. Language can 
affect pupil participation in unpredictable ways. It could give 'room for maybe quiet ones' (Teacher 2) or be an impetus for a more 'active role' (Teacher 6) and motivation, but it could also make pupils question 'the whole idea of CLIL' (Teacher 4), thus giving rise to attitudes that present an 'obstacle' for teachers (Teacher 4). Additionally, CLIL might have 'definitely taught [teachers] to use the language in the classroom [...] in a more effective way' (Teacher 14), but teachers felt that conversations in English 'won't go so deep' (Teacher 6), and teacher-pupil relationships can be constricted in part by the pupils' very young age and availability of linguistic resources. That, however, can become an occasion for more dialogic teaching, allowing more teacher-pupil negotiation on social and interpersonal dynamics (e.g. Nikula 2010). Language is very much involved in teaching and learning, and becomes even more important when it is a foreign channel of communication, requiring acceptance and output from pupils, and explanations and resolve from teachers. This theme remains significant in relation to the other perceived tensions, factoring as a mediating and permeating element.

\section{Classroom-related Tensions}

Classroom-related tensions concerned the CLIL classroom as a sphere of teacher action and teacher-pupil interactions. Many teachers (10/14) discussed teacher-pupil relationships, referring to them as a source for their own learning as teachers as well as for their pupils' learning, and as 'the beginning of all learning at school' (Teacher 4) for teacher and pupil alike. This bidirectional learning taking place through a foreign language entails giving and receiving feedback, communication, an adjustment of teacher expectations, and a gradual growth in terms of connection:

I have built a, sort of, a secure [environment]. And so it's, it's nice where you can, it doesn't matter if you make mistakes. [...] I think that's the best. [...] So, it's nice to hear my own pupils to say that this is working, even they are not saying that that 
way, but I feel that this is something that I need to do more. [...] Also we teachers learn from the children (Teacher 5)

However, for better communication and learning, three teachers suggested smaller class sizes, while the importance of being organized (2/14), planning lessons well (7/14) and preparing material (8/14) was also discussed. Yet, the latter demand 'time and effort' (Teacher 3). The teacher acts as a mediator of the methodology, making it not only a less daunting experience, but also available to and useful for everyone. Therefore, it should not be surprising that successfully integrating content and language (7/14), identifying priorities in CLIL (7/14), such as making or sustaining positive pupil attitudes towards learning and languages, attempting to integrate all pupils into CLIL (3/14), and determining pupil assessment (4/14) were issues that concerned some teachers. However, teachers' hopes for pupils' learning (3/14) and seeing the potential and benefit of CLIL (6/14), such as raised linguistic awareness (5/14), might be helping teachers persist or guiding them throughout the process. As a theme, classroom-related tensions give a picture of what happens in the physical and relational space where teachers and pupils spend most of their school day. Teachers were aware of responsibilities and existing needs, to which they try to respond successfully. Yet, there are things that are sometimes beyond their control, such as pupil participation, using more advanced language, and class sizes, whose affect they try to remediate by being well prepared and drawing on the perceived meaningfulness of CLIL. Awareness and action combined could be an invaluable tool for teachers' pedagogical agency, yet the effects of such combination are always dependent on environmental factors and teachers' willingness to persevere. 


\section{Availability of Temporal, Material and Developmental Resources}

The availability of resources was perceived as a tension. Teacher 8 claimed that '[they] get less resources and the new curriculum, for example, requires a lot of resources'.

When asked about what helps them in developing CLIL lessons, teachers referred to the Internet, props, other teachers' materials, to pupils' ideas and collaboration, and cooperation with other people. Yet, 'CLIL, for a large part, is using your own creativity' (Teacher 12). Moreover, in-service opportunities for professional development were found to be important to most teachers $(10 / 14)$ as a place to get expert advice or ideas for their work, meet and discuss with colleagues working at other schools, get qualifications, and learn about new developments. The provision of time and space to share and reflect with colleagues was considered the most valued professional benefit of such in-service training. After attending a course on critical thinking abroad, Teacher 10 remarks:

I've never been to a, like, course like that and it really opened up my eyes, thinking that what kind of a teacher I am, and what's my role, and what do the pupils do in my classroom. And forever since, eh, I just go back to what I used to be in a way, that even if it says in our old curricula, and it emphasizes the, like, teaching thinking skills a lot in the new curricula, I don't think Finnish teachers or I haven't understood what that actually means.

International projects for the benefit of pupils, exchange programmes for teachers, and cooperation with teacher trainees from foreign universities were also mentioned as important resources. Most teachers actively sought or were granted such in-service opportunities for training and professional development, while there was a general appreciation of and interest in them.

On the other hand, one teacher mentioned outdated CLIL-related web pages and five teachers hinted at the need for more funds that could be used for material and in- 
service training. Five teachers commented on the excellence of Finnish school books, while one claimed they were old and incompatible with the curriculum. In all cases it was stated that there was no mere reliance on books for teaching, but teachers consulted the curriculum, prepared handouts and new material, and sought new information. Resources that are easy to reach or readily available seemed to be managed well by teachers, yet funding remained an issue for them.

\section{Resourcing Factors}

In the analysis, four themes were considered to act as a resource for CLIL teachers' agency: i) autonomy, ii) openness to change, iii) teacher versatility, and iv) collegial community. In the following section these themes are described in more detail and illustrated with examples.

\section{Autonomy}

Most participants (13/14) reported that they experience autonomy at work. At the level of the classroom, autonomy concerned teaching style and versatility in the implementation of CLIL, decision making with regard to the curriculum, using one's own material with confidence, and working according to one's ethical principles. Amongst colleagues, autonomy concerned a feeling of being valued for one's work performance and contribution of experiences, while amongst stakeholders it involved joint decision making by having a say in matters of pedagogy as well as communication and cooperation with parents. Autonomy requires an investment of interest and trust, such as by school leadership and parents:

I think most of the parents are, are very interested in what their children do, but there's really nice peace for me to do things the way I do. I met most of the parents in the fall, only like two weeks after school started, and the atmosphere was really 
nice. And hopefully they saw [laughs] something they like, because it's been really quiet from the parents' side (Teacher 8)

However, according to Teacher 14, while teachers are trusted enough not to be questioned or observed and monitored in the classroom, it 'sometimes might be good to get some feedback' (Teacher 13). Autonomy also entails a sense of agency coupled with possibilities of influence at work and the disposition to question. For example, while teachers might feel responsible or willing to effect changes and take an active role (Teachers 2 and 9), they also have to be 'very flexible and [a] little humble as well', because '[i]t's a different constellation every year' (Teacher 4), while being critical about curricular demands (5/14). Autonomy at work is important not only for creativity and change, but also for an overall sense of well-being at work.

\section{Openness to Change}

Most interviewees (13/14) exhibited an openness to change. Firstly, such openness was evident in the unplanned way teachers started CLIL (9/14), either by starting studying it at university without directly applying for a CLIL training programme (4/14) or by accepting the challenge due to a change in school (5/14). As Teacher 13 characteristically says, 'Well, I first came in contact with it while I was still at university doing my last year as a teacher trainee. Um, I- I've never heard of it before.' Secondly, openness towards change takes the form of adjustment to or acceptance of new work situations and school culture (9/14). The fact that while teachers might feel 'pressure', they might still 'have a little growing interest to have more courage maybe to go towards new things' is encouraging (Teacher 2). Talking about the new curriculum, Teacher 5 mentions that 'when it's on the paper, what does change, so it's, it's good that it's done now, because the school needs, needs to change, but not too quickly'. For her 
part, teacher 12 comments:

I think where Finnish educational system is going with the new curriculum especially, um, I think it's connected really well. I think the... like, the, what we are aiming at is pretty similar actually. [...] The methods and, and the ways how to- how learning should be. It's, it's not that far, far form that. CLIL is not that traditional way of teaching.

Teachers emphasized that it is important that time be given for changes to fall into place with the daily school life of teachers, so that their embeddedness in everyday pedagogical practices is also reflected in teachers' internalization of their purpose. Thirdly, reflection is also essential to the reception or rejection of change. Most participants (9/14) acknowledged being reflective about their role, beliefs, abilities and progress as an individual action that can help monitor and assess one's overall performance. Fourthly, lifelong learning (6/14) and professional development (10/14) were mentioned as two more important components to openness to change, as they propel teachers to learn about and try out new methodologies, improve on their skills, keep abreast of current educational research and learn through the long-term results of their teaching practices. Openness to change is a significant characteristic of teachers' lives, since it encourages the pursuit of different routes of action, and facilitates professional development and innovation (e.g. Wanberg and Banas 2000; Katelaar et al. 2012).

\section{Teacher Versatility}

A perceived versatility was identified from the teachers' responses (14/14). Teacher versatility was manifested in varying the educational approach or initiating methodological change (10/14), and potentially transferring practices from CLIL to regular teaching (7/14). Teacher versatility predominantly concerns the classroom and 
couples well with autonomy and openness to change, the former being invested in teachers and the latter a characteristic of the teacher. Its importance for teacher agency lies in maintaining an active stance towards classroom events and pedagogical practices, and being able to manoeuvre adequately amidst them when necessary. As such, it represents an aspect of pedagogical agency that is crucial for effectively carrying out teaching and pedagogical responsibilities, and maintain enthusiasm (e.g. Billett and Pavlova 2005; Kunnari and Ilomäki 2016).

\section{Collegial Community}

The findings show that teachers perceived they had collegial communities, salient features of which were collegial relationships (11/14), cooperation (8/14) and collaboration (5/14). Teachers discussed collegiality as a resource whereby they can learn, practice English skills, discuss CLIL and instructional issues more deeply, codesign and tailor teaching material, complement another's class (e.g. team teaching), and enhance their connection to the teacher community. The following excerpt echoes the appreciation participants had for their colleagues:

\footnotetext{
Um, that's a lovely question, and sometimes I've thought that, um, I think, I think [briefly laughs], what comes into my mind is my lovely colleagues that kind of can see something in you that will grow there. [...] I think I, I owe to, lot, lot to my lovely colleagues. The support, and, and the cooperation it kind of inspires and I think that's, has helped, and I have, I have, I feel like I'm grateful to, for many of my colleagues (Teacher 2)
}

Asking (7/14), sharing (10/14) and talking (7/14) were found to be other aspects of relationships within such a community. The teachers seemed keen to engage in an exchange of practices, ideas and materials, experience and knowledge. Moreover, they actively sought communication with colleagues, who also seem to be the primary or 
most immediate source of help:

But then, if you think of, like, that there are those stressful moments and where to get support, I think that that's also more or less, um, our own staff. (Teacher 3)

Knowing that there are help and advice available and given if asked for is important for a sense of security and for overcoming difficulties at work, which can help one learn and progress. Teachers' relational agency was also evident in their involvement in projects or research, developmental or curriculum work, and CLIL associations or CLIL teams (9/14). While such involvement can be regarded by some as 'extra' (Teacher 5) and time-consuming, it is worth remarking the importance for teachers' ability to influence their work and practices within the structural and relational space offered at the school level by means of active participation. Support at school extends from colleagues to school leadership (10/14) which, according to the interviewees, should be helpful, support teachers' feasible ideas, trust them as professionals and take initiatives to aid teachers in their work, such as inviting native speakers to the school or being involved in development work alongside teachers. Last but not least, teacher assistants and substitute teachers were also found to be a source of support for some participants (4/14), as they assist teachers in providing pupils with the support they need. A supportive and collaborative collegial atmosphere in conjunction with good school leadership and in-class assistance can be a strong foundation for teachers' relational, and by extension pedagogical or sociocultural, agency. In addition, it could also mean a firmer ground to stand on or a vast resource for new teachers and for teacher trainees alike.

\section{Discussion}

This study provides a view into the tensions and resources of teacher agency in Finnish 
CLIL education in primary schools. With regard to the first research question - What tensions do CLIL teachers in Finland recognize in exercising agency in their work? three themes were identified, drawing on language, the classroom, and resources. In answer to the second research question - What enables and resources CLIL teachers in Finland to deal with tensions at work? - four themes were identified. Autonomy, openness to change and teacher versatility primarily concerned the teacher herself, while collegial community regarded the immediate collegial environment. In this section, the significance of these findings is discussed in the light of literature on agency before touching upon limitations and elaborating on the practical implications of the study.

Firstly, the study brings the matter of professional identity to the fore with an emphasis on how language mediation and perceived hindrances to exercising teacher agency can affect one's sense of self within the profession. In this study, teacher-pupil relationships offered opportunities for bidirectional learning, yet were counterbalanced by teachers' instructional responsibilities, challenges and concerns. Participants' perceived emphasis of CLIL on active learning and usage of language might indicate that teachers needed to be more active themselves. However, language was an element that would not always favour participants' lesson plans, and could be regarded by some as a temporary impediment and by others as an ever-present, yet positively perceived, challenge to teaching and learning. The relationships and experiences created by teachers' proactivity and reactivity within the classroom potentially nourish the development of teachers' identity (Ruohotie-Lyhty and Moate 2016). It is, therefore, pertinent to better teacher-pupil communication, classroom practices and meeting curriculum demands that attention is drawn to the professional development and identity negotiation of CLIL teachers in primary education. However, it was evident that the 
CLIL teachers of this study were not entirely self-sufficient in their identity

development, but dependent from the support offered by other practicing CLIL teachers. To further professional development within CLIL, the creation of a support network for teachers that are largely working alone could be of critical importance (Lehti, Järvinen, and Suomela-Salmi 2006; Moate 2014).

Secondly, the findings raise the issue of pedagogical agency in CLIL, since language use, autonomy, openness to change and teacher versatility were related to exercising agency at the classroom level. These themes resonate with a view of agency as involving conscious action and choice-making, according to what is educationally beneficial and in conjunction with the physical and interpersonal resources of the working environment (Eteläpelto et al. 2013; Moate and Ruohotie-Lyhty 2014; Toom, Pyhältö, and Rust 2015). Nonetheless, although language is acknowledged by participants as a self-evident tool in CLIL teaching, the study also showed some of the less acknowledged effects of language on CLIL teacher agency. The participants struggled to construct pedagogical relationships with their pupils and raised the meaning of language for classroom interactions. As a consequence, the language shaped the participants' subjectivity as teachers (Nikula et al. 2016) and forced them to reconsider their teacher role. Aside from language, autonomy was felt not only because teachers believed they were able to follow the instructional material and styles of their choice at work, but also because curriculum guidelines coupled with trust, involvement and appreciation on the part of stakeholders, like school administration and parents, afforded them space for individual action and decision-making. In addition, a positive attitude towards both short-term and long-term changes coupled with instances of reflection and self-evaluation may be conducive to mindful, varying and creative educational approaches. These three themes indicate that teachers need to be to some extent flexible 
in order to better incorporate changes into their daily schedules and practices and, by extension, their careers. For example, in stark contrast to the textbook-supported mainstream Finnish classroom, CLIL teachers have to be material designers themselves, since there are no ready-made materials tailored to the varying needs of CLIL pupils (Atjonen et al. 2008). Moreover, as bilingual education becomes more popular in Finland and starts earlier in education, teachers should be more involved in implementing bilingual models and engaging in "educational partnerships" with parents for children's target language development and attitudes (Schwartz and Palviainen 2016). However, this flexibility needs to be supported and enhanced by the social and structural frames determining their classroom practices. Although CLIL teachers are enthusiastic at first, lack of sufficient support for them as gatekeepers of education and mediators of the curriculum can cause innovation to fail by minimizing its potential (e.g. Pyhältö, Pietarinen, and Soini 2015). While pedagogical agency appears to rest on CLIL teachers' judgment and action, it is in fact also linked to the sociocultural environment, which delineates the area of possible agency by means of relationships, policies and material resources.

Thirdly, this study highlights the importance of a collegial community, and consequently of relational agency, for CLIL teachers. Similarly to Eteläpelto et al.'s (2015) study on novice Finnish teachers' perception of professional agency, close collaboration with colleagues and their being an immediate source of help were major resources for teachers. In addition, CLIL teachers' participation in organizational activities at school level, and the sharing of ideas or material showed a strong sense of agency in working within their community. As members of collegial communities, they contribute intellectual, social and material resources (Little 2002). While this holds true for any teaching context, it is even more salient in CLIL due to the isolation in which 
many teachers work in schools, and the additional effort required to be successful and effective with respect to material design and language mediation. CLIL teachers' investment in collegial relationships and cooperation stress the importance of strengthening teachers' relational agency as a key factor for both collective and individual autonomy. Teachers traditionally view themselves as pedagogically-based professionals, yet relationships and shared responsibility in a collegial community can provide support for initiatives, resistance and change on a collective level (Edwards 2015). At the level of the CLIL classroom, joint action can strengthen individual agency through material and conceptual resources that make sense-making and object-oriented activities clearer (Edwards 2007). Facilitating and making time for teacher interactions would be fruitful for pedagogical practices and involvement in the work community, which supportive school leadership can greatly advance (Thoonen et al. 2011).

To conclude, mutual pedagogic relationships amongst colleagues can support teacher development and an enriched critical understanding of pedagogy (Moate 2014). This is supported by the importance practicing CLIL teachers gave to their community in this study. Compared to some other studies about the constraints and enabling factors that teachers perceive in their environment (see Ruohotie-Lyhty and Moate 2016), this study also highlighted the participants' versatility, openness to change and autonomy. This might suggest that the CLIL teaching context presents a pronounced need for relational and sociocultural components of teacher agency, when it does not occur within established support networks and clear institutional regulations. By supporting that agency, we can enhance teachers' diverse learning, the pursuit of their professional orientations, their well-being and commitment (Hökkä and Vähäsantanen 2014). Compared to a monolingual environment, bilingual education in this study emphasized 
teachers' ability to connect and negotiate the increasing tensions of the environment with the help of their personal and environmental resources.

The limitations of the present study concern timeframe, scope and participant gender. The interviews took place in the space of two months, as we were mostly interested in an overview of resourcing and constraining factors. Two sets of interviews might have given more information, but the teachers' busy schedule might have discouraged participants from participating in another interview. Moreover, although participants worked in different cities, some worked at the same school. This might have resulted in a similarity of views, for example regarding collegial collaboration. If the interviewees had all taught at different schools, their responses might have provided a more diverse picture. Additionally, all interviewees were women, which leaves male teachers' voices unheard, although a majority of female respondents was expected due to the numerical dominance of women in the teaching profession. Nonetheless, the relative similarity of the responses received suggests that male teachers might have responded similarly. Future research could focus on case studies or male teachers.

\section{Implications}

This study draws attention to the support teachers need to succeed in teaching CLIL. Practical implications are discussed in light of pre-service teacher education, in-service opportunities and research. The study suggests that teacher training should go beyond mere expertise and cultivate collaboration and joint meaning making. During the formative years of teacher training, an open and cooperative relationship with mentors and supervisors alike could foster a sense of community and safety for confronting tensions at work and support teachers in making sense of their professional identity. In addition to the ability to build collegial relationships, this study also raised language as 
a central element in creating and maintaining relationships and expressing emotions in the classroom. In the light of this, the education of pre-service teachers should include a component of language not just as a medium of instruction, but as an organizational tool in maintaining relationships. This aspect has been already taken into account in some CLIL programs, e.g. at the University of Jyväskylä where a course entitled "The Language of Education and Pedagogy" has been introduced to encompass the different dimensions of language in the classroom. Moreover, autonomy and versatility should be encouraged during practicum, as they enable prospective teachers to be more selfsufficient and flexible, traits which act as precursors to innovation in their teaching. Finally, a learning portfolio could regularly be maintained from the beginning of pupilteachers' studies and complemented along the way with reflections on personal and vicarious teaching experiences, so as to promote self-monitoring and self-regulation, planning and goal-setting, understanding one's beliefs and perceptions, and gradual ownership of theory and practice.

Concerning in-service CLIL teachers, the study suggests that opportunities for learning and further education entail critical thought-provoking encounters which can foster more original and reflective pedagogical CLIL practices in the future. This can be effected by organizing workshops or seminars at a local - not only national - level and at times that are possible for teachers to attend. Most importantly, the in-service education continuum could continue either within teacher-initiated communities or in partnership with universities and institutions for a more organized and research-based provision of training. International experiences could also be organized and partly funded regularly for teachers and pupils, which can act both as a reward and incentive by bringing the wider significance and implications of CLIL teaching to bear on one's perception of its purpose. Thus, awareness concerning EU funding possibilities for 
teacher exchange is important. In addition, more language support could be offered to CLIL pupils to strengthen CLIL teaching, while a more concrete framework for such teaching could better guide teachers in organizing and implementing methodology in and across CLIL classes. The latter, on the one hand, requires a more prominent presence of CLIL in the national curriculum with corresponding pedagogical guidelines and specified goals. On the other hand, it requires inclusion and involvement of CLIL teachers not only in designing that section of the curriculum, but also in translating it at regional, school and classroom level. This could be achieved by creating regularlyconvening CLIL teams that transcend school, disciplinary and geographical boundaries. Additionally, to meet the national need for language-aware teachers irrespective of background set forth by the national curriculum, the supportive relationship of skills and beliefs in both regular and CLIL teaching should be reinforced (Nikula et al. 2016). Finally, it is important for teachers' efficacy and well-being at work that they be allowed sufficient time in their schedule to share everyday school experiences, discuss and plan with colleagues. This could be done by designating time for CLIL team work, for example to create material banks, or by informally cultivating a nested environment of positive interdependency (Pyhältö, Pietarinen and Soini 2015). Agency should be sustained and encouraged throughout teachers' careers and couple classroom, collegial relations and social structures.

Regarding theoretical conclusions, the differentiation of teacher agency used in this study reflected the reported experiences of teachers. Nonetheless, the identified resourcing factors indicate that the differentiation should be enriched with issues concerning teacher identity. By examining the role and aspects of CLIL teachers' professional identity, we could gain a more comprehensive understanding of how agency is enacted in the negotiation of teacher identity in everyday school life. 
However, this study highlights the importance of understanding CLIL teacher agency and the ongoing development of CLIL pedagogical practices in Finnish primary education.

Acknowledgements

The authors would like to thank the CLIL teachers for sharing their thoughts and experiences for the purpose of this study. We also thank the reviewers for their insightful comments and suggestions. 
References

Atjonen, P., I. Halinen, S. Hämäläinen, E. Korkeakoski, G. Knubb-Manninen, P. Kupari, J. Mehtäläinen, A.-M. Risku, M. Salonen, and T. Wikman. 2008. "Tavoitteista vuorovaikutukseen." Perusopetuksen pedagogiikan arviointi. Koulutuksen arviointineuvoston julkaisuja 30 (2008).

Ahearn, L. M. 2001. "Language and Agency.” Annual Review of Anthropology 30 (1): 109-37. doi:10.1146/annurev.anthro.30.1.109

Baetens-Beardsmore, H. 2008. "Multilingualism, Cognitions and Creativity." International CLIL Research Journal 1: 4-19. Accessed 20 January 2015 from http://www.icrj.eu/11/article1.html

Bergroth, M. 2016. "Reforming the National Core Curriculum for Bilingual Education in Finland." Journal of Immersion and Content-Based Language Education 4 (1): 86-107. doi:10.1075/jicb.4.1.04ber

Biesta, G., M. Priestley, and S. Robinson. 2015. "The Role of Beliefs in Teacher Agency." Teachers and Teaching: theory and practice 21 (6): 624-640. doi:10.1080/13540602.2015.1044325

Billett, S., and M. Pavlova. 2005. "Learning Through Working Life: Self and Individuals' Agentic Action.” International Journal of Lifelong Education 24 (3): 195-211. doi:10.1080/02601370500134891

Bovellan, E. 2014. "Teachers' beliefs about learning and language as reflected in their views of teaching materials for Content and Language Integrated Learning (CLIL).” PhD diss., University of Jyväskylä. Retrieved 18 December 2014 from http://urn.fi/URN:ISBN:978-951-39-5809-1 
Coyle, D. 2006. "Content and Language Integrated Learning Motivating Learners and Teachers.” Scottish Languages Review 13: 1-18. Retrieved 19 August 2016 from http://www.scilt.org.uk/Portals/24/Library/slr/issues/13/SLR13_Coyle.pdf

Dalton-Puffer, C. 2011. “Content-and-Language Integrated Learning: From Practice to Principles?” Annual Review of Applied Linguistics 31: 182-204. doi:10.1017/S0267190511000092

Edwards, A. 2007. "Relational Agency in Professional Practice: A CHAT Analysis." An International Journal of Human Activity Theory 1: 1-17. Retrieved 10 January 2015 from http://www.chat.kansai-u.ac.jp/publications/actio/pdf/1_Edwards.pdf

Edwards, A. 2015. "Recognising and Realising Teachers' Professional Agency." Teachers and Teaching: theory and practice 21 (6): 779-784. doi:10.1080/13540602.2015.1044333

Eteläpelto, A., K. Vähäsantanen, and P. Hökkä. 2015. "How do novice teachers in Finland perceive their professional agency?" Teachers and Teaching: theory and practice 21 (6): 660-680. doi:10.1080/13540602.2015.1044327

Eteläpelto, A., K. Vähäsantanen, P. Hökkä, and S. Paloniemi. 2013. "What is agency? Conceptualizing professional agency at work.” Educational Research Review 10: 45-65. doi:10.1016/j.edurev.2013.05.001

Eurydice. 2014. "Language in Education and Training: Final Country Comparative Analysis.” Retrieved 08 March 2016 from $\underline{\text { http://ec.europa.eu/languages/library/studies/lang-eat_en.pdf }}$

FNBE (Finnish National Board of Education). 2014. Core curriculum for basic education 2014. Retrieved 18 April 2016 from http://www.oph.fi/english/curricula_and_qualifications/basic_education.

Holloway, W., and T. Jefferson. 2000. Doing Qualitative Research Differently: Free Association, Narrative and the Interview Method. London: Sage Publications. 
Hökkä, P., and K. Vähäsantanen. 2014. “Agency-Centred Coupling - A Better Way to Manage an Educational Organization?" International Journal of Leadership in Education: Theory and Practice 17 (2): 131-153.

doi:10.1080/13603124.2013.783932

Ketelaar, E., D. Beijaard, H.P.A Boshuizen, and P.J. Den Brok. 2012. “Teachers' Positioning Towards an Educational Innovation in the Light of Ownership, Sense-making and Agency.” Teaching and Teacher Education 28 (2): 273-282. doi:10.1016/j.tate.2011.10.004

Kunnari, I., and L. Ilomäki. 2016. 'Reframing Teachers' Work for Educational Innovation.” Innovations in Education and Teaching International 53 (2): 167178. doi:10.1080/14703297.2014.978351

Lehti, L., H.-M. Järvinen, and E. Suomela-Salmi. 2006. Kartoitus vieraskielisen opetuksen tarjonnasta peruskouluissa ja lukioissa [Mapping FL Learning in Comprehensive and High Schools]. In Kielenoppija tänään [Language Learners of Today], edited by P. Pietilä, P. Lintunen, and H.-M. Järvinen, 293-313. Jyväskylä: AFinLA.

Little, J. W. 2002. “Locating Learning in Teachers' Communities of Practice: Opening up Problems of Analysis in Records of Everyday Work." Teaching and Teacher Education 18: 917-946. doi:10.1016/S0742-051X(02)00052-5

Marsh, D. 2012. “CLIL/EMILE - the European Dimension: Actions, Trends and Foresight Potential.” Jyväskylä: UniCOM. Retrieved 09 March 2016 from https://jyx.jyu.fi/dspace/bitstream/handle/123456789/47616/david_marshreport.pdf? sequence $=1$

Marsh, D., P. Mehisto, D. Wolff, and M.J Frigols. 2014. "European Framework for CLIL Teacher Education.” Retrieved 09 March 2016 from http://www.unifg.it/sites/default/files/allegatiparagrafo/20-012014/european framework for clil teacher education.pdf 
Masih, J. Forward to Learning through a Foreign Language: Models, Methods and Outcomes by J. Masih (Ed.), 8-12. Lancaster: CILT, 1999.

Ministry of Education. 1998. Basic Education Act. Retrieved 24 August 2016 from http://www.finlex.fi/en/laki/kaannokset/1998/en19980628.pdf

Moate, J. 2011. “The Impact of Foreign Language Mediated Teaching on Teachers' Sense of Professional Integrity in the CLIL Classroom." European Journal of Teacher Education 34 (3): 333-346. doi:10.1080/02619768.2011.585023

Moate, J. 2013. "Reconceptualising Teacherhood through the Lens of ForeignLanguage Mediation.” PhD diss., University of Jyväskylä. Retrieved 16 December 2014 from https://jyx.jyu.fi/dspace/bitstream/handle/123456789/40738/978-951-39-50347.pdf? sequence $=1$

Moate, J. 2014. "A Narrative Account of a Teacher Community.” Journal of Teacher Development 18 (3): 384-402. doi:10.1080/13664530.2014.931294

Moate, J., and M. Ruohotie-Lyhty. 2014. "Identity, Agency and Community: Reconsidering the Pedagogic Responsibilities of Teacher Education.” British Journal of Educational Studies 62 (3): 249-264. doi:10.1080/00071005.2014.955456

Morton, T. 2012. "Classroom Talk, Conceptual Change and Teacher Reflection in Bilingual Science Teaching.” Teaching and Teacher Education 28 (1): 101-110. doi:10.1016/j.tate.2011.07.006

Nikula, T. 2010. "Effects of CLIL on a teacher's classroom language use.” In C. Dalton-Puffer, T. Nikula \& U. Smit (eds.) Language use and Language Learning in CLIL Classrooms. Amsterdam: John Benjamins, 105-123. Accessed 25 August 2016 from https://books.google.fi/books?hl=fi\&lr=\&id=lT0zAAAAQBAJ\&oi=fnd\&pg=PA105\& 
$\underline{\mathrm{dq}}=$ Nikula,$+\mathrm{T} .+2010 .+$ Effects + of + CLIL+on+a+teacher $\% E 2 \% 80 \% 99 \mathrm{~s}+$ classroom $+\mathrm{l}$ anguage + use. + In+C.+Dalton-

Puffer,+T.+Nikula+\%26+U.+Smit+(eds.)+Language+use+and+Language+Learning +in+CLIL+Classrooms.+Amsterdam:+John+Benjamins, $+105-$

123.\&ots=FkGOuAKipV\&sig=bmk2om0YBKGZNLBAghg6xU4keZk\&redir esc=y\#v= onepage\&q\&f=false

Nikula, T., E. Dafouz, P. Moore, and U. Smit (eds.). 2016. Conceptualising Integration in CLIL and Multilingual Education. Bristol, UK: Multilingual Matters.

Patton, M. Q. 2015. Qualitative research \& evaluation methods: integrating theory and practice. Fourth edition. Thousand Oaks, California: SAGE Publications, Inc.

Pyhältö, K., J. Pietarinen, and T. Soini. 2015. “Teachers' Professional Agency and Learning - From Adaption to Active Modification in the Teacher Community." Teachers and Teaching 21 (7): 811-830. doi: 10.1080/13540602.2014.995483

Ruohotie-Lyhty, M., and J. Moate. 2015. "Proactive and Reactive Dimensions of LifeCourse Agency: Mapping Student Teachers' Language Learning Experiences.” Language and Education 29 (1): 46-61. doi:10.1080/09500782.2014.927884

Ruohotie-Lyhty, M., and J. Moate. 2016. "Who and How? Preservice Teachers as Active Agents Developing Their Identity." Teaching and Teacher Education 55: $318-327$.

Schwartz, M., and Å. Palviainen. 2016. “Twenty-first-century Preschool Bilingual Education: Facing Advantages and Challenges in Cross-cultural Contexts." International Journal of Bilingual Education and Bilingualism 19 (6): 1-11. http://dx.doi.org/10.1080/13670050.2016.1184616

Tedick, D., and L. Cammarata. (2012). "Content and Language Integration in K-12 Contexts: Student Outcomes, Teacher Practices, and Stakeholder Perspectives.” Foreign Language Annals 45 (S1): S28-S53. doi:10.111/j.19449720.2012.01178.x. 
Thoonen, E.E.J., P.J.C. Sleegers, F.J. Oort, T.T.D. Peetsman, and F.P. Geijsel. 2011. "How to Improve Teaching Practices: The Role of Teacher Motivation, Organizational Factors, and Leadership Practices.” Educational Administration Quarterly 47 (3): 496-536. doi:10.1177/0013161X11400185

Toom, A., K. Pyhältö, and F.O.C. Rust. 2015. “Teachers' Professional Agency in Contradictory Times." Teachers and Teaching 21 (6): 615-623.

Vaismoradi, M., J. Jones, H. Turunen, and S. Snelgrove. 2016. "Theme Development in Qualitative Content Analysis and Thematic Analysis.” Journal of Nursing Education and Practice 6 (5): 100-110. doi:10.5430/jnep.v6n5p100

Wanberg, C.R., and J.T. Banas. 2000. "Predictors and Outcomes of Openness to Changes in a Reorganizing Workplace." Journal of Applied Psychology 85 (1): 132-142. http://dx.doi.org/10.1037/0021-9010.85.1.132 
Table 1. Information on participants

\begin{tabular}{|c|c|c|c|}
\hline \multicolumn{4}{|c|}{ Participant Information } \\
\hline Teacher & School & Qualifications & Years of experience \\
\hline 1 & \multirow[t]{2}{*}{ primary } & minor studies in English & 1 \\
\hline 2 & & specialization in Music, Art and English & 20 \\
\hline 3 & kindergarten & in-service training & 25 \\
\hline 4 & \multirow[t]{11}{*}{ primary } & $\begin{array}{l}\text { PhD, CLIL courses after starting teaching } \\
\text { CLIL }\end{array}$ & 30 \\
\hline 5 & & specialization in English & 30 \\
\hline 6 & & learning CLIL from colleagues & 20 \\
\hline 7 & & PhD, specialized in English and German & 26 \\
\hline 8 & & minor studies in English & 8 \\
\hline 9 & & minor studies in English & 13 \\
\hline 10 & & specialization in English & 21 \\
\hline 11 & & $\begin{array}{l}\text { specialization in Music and English, CLIL } \\
\text { teacher qualification exam }\end{array}$ & 27 \\
\hline 12 & & $\begin{array}{l}\text { specialization in English, in-service CLIL } \\
\text { training }\end{array}$ & 16 \\
\hline 13 & & BA in bilingual education & 5 \\
\hline 14 & & minor studies in English & 3 \\
\hline
\end{tabular}


Table 2. Steps of data analysis

\begin{tabular}{|c|c|c|}
\hline \multicolumn{3}{|c|}{ Steps of Data Analysis } \\
\hline Steps & Actions taken & Examples \\
\hline $1 \mathrm{st}$ & Coding in detail & $\begin{array}{l}\text { Intense cooperation in CLIL } \\
\text { Designing material improving teacher } \\
\text { cooperation } \\
\text { Assessment and teacher cooperation } \\
\text { Collegial cooperation }\end{array}$ \\
\hline 2nd & $\begin{array}{l}\text { Grouping codes and naming } \\
\text { basic themes }\end{array}$ & Collegial cooperation \\
\hline 3 th & Identifying illustrative excerpts & $\begin{array}{l}\text { "And they can help me with anything, and } \\
\text { we do cooperation together. So we can } \\
\text { have- not with all the CLIL classes, we } \\
\text { haven't had cooperation, but with few } \\
\text { we've had some projects together or some } \\
\text { artwork together maybe or something, so." } \\
\text { (Teacher } 14 \text { ) }\end{array}$ \\
\hline 4th & Identifying key themes & $\begin{array}{l}\text { 'Collegial cooperation' under 'Collegial } \\
\text { relationships' }\end{array}$ \\
\hline 5 th & $\begin{array}{l}\text { Joining key themes under } \\
\text { overarching themes }\end{array}$ & $\begin{array}{l}\text { 'Collegial relationships' } \\
\text { 'Resourcing factors' }\end{array}$ \\
\hline
\end{tabular}

